\title{
ZU PARTANOPE OF BLOIS.
}

Gower erwähnt in seiner 43. ballade unter andern sagenstoffen auch Parlanope. ${ }^{1}$ Obgleich die ballade in französischer sprache abgefasst ist, so durfen wir hier doch wol an ein gedicht in Englisch denken, worauf der dichter anspielt. Es ist uns nun auch ein englisches gedicht erhalten, das dicsen stoff behandelt, und es wurde dies nach einer nicht vollständigen handscbrift von W. E. Buckley für den Roxburghe Club heransgegeben. ${ }^{2}$ Da Buckley diese handschrift des 15. jahrhunderts als unique bezeichnet, so dürte es nicht uninteressant sein, wenn für einen etwaigen herausgeber des gedichtes noch folgende bruchstticke abgedruckt werden. Ich liess sie fruher einmal in der absicht, dieses gedicht neuherauszugeben, abschreiben. Die abschrift ist von herrn Georg Parker auf der Bodleiana angefertigt (1882) und öfter mit der urhandschrift verglichen worden. Da mir hier kein abzug des abdrucks des Roxburghe-Clubs zur hand ist, so unterlasse ich eine vergleichung desselben.

Die abgedruckten handschriften sind nach Parker's angabe aus dem 15. jahrhundert.

Es wurde mich sehr freuen, wenn jemand unter den jungeren fachgenossen durch diese veröffentlichung veranlasst wtirde, den Partanope of Blois einmal neuherauszugeben.

1 Vgl. Ballads and other Poems, by John Gower. Printed from the Original Manuscript in the Library of the Marquis of Stafford at Trentham. Printed for the Roxburghe Club, 1818.

${ }^{2}$ Gedruckt $1862.4^{\circ}$. 
A Fragment of a $15^{\text {th }}$ Century MS. (belonging to Lord Robartes) with corresponding Portions from the University College MS., Oxford.

UNIVERSITY COLLEGE MS. 188.1

(p. 94) [Hur bell which was hevy to bere ${ }^{2}$

$3430^{*}$

This lady had both shame and fere

For she was in right grete doute

$3432^{*}$

Hur women stode rounde aboute

Hur bede and pressede wonder nyghe

To have a sight of hur lady

On hur they loke wonder faste

And nere they come at the laste

Hur lady better to devyse

Then they thought in all wyse

And she had ben glad and not hevy

$3440^{*}$

The hade beute not passyngly

Hur beute made hur maly[n]coly sese

(p. 95) So that there was none of that prese

That they ne were in hert sory

That they had so reprovyde their lady

And all stode still in on acorde

That none of hem durste say a worde

q With in a while come in anone

$3435^{*}$

A symly lady and a fayre one

In hir persone was fonde no lake

$3145^{*}$

Hir here henge tressede at hur bake

Well hangynge downe at her feete

She of her beute to other was mete

And so haunswerynge in iche degre

That she was pressede passynge of beute $3455 *$

Her array to reherse to reherse ${ }^{3}$ here

Hit nedyth not for in beste manere

She was arrayde in the beste that freshe may

Who so luste to here of hir arraye

Let hym go to the frenche boke

And who-so will it overloke

To tell it in prose or in ryme

For me it were a longe tyme

1 See the text printed by the Roxburghe Club, p. $272 . \quad{ }^{2}$ From 1. $3430^{*}$ to $1.3482^{*}$ are from the MS. Rawl. Poetry $14 .{ }^{3}$ Sic! 


\section{LORD ROBARTES' MS.}

$\begin{array}{lll}* & * & * \\ * & * & *\end{array}$

[For sh]e was in ryght gret doute

[Hur w]ommen stode all rownde a-boute

[Hur be]d and presed wondyr nye

[To hav]e a syght off hur lady

2435*

[On hur] they lokyn wondyr fast

[And ne]rre they come att pe last

[Hur la]dy better to A-Vyse

[Th]an thay thowght in alt wyse

[And sh]e had ben glad and not heuy

[She ha]d beuate 1 and not passyngly

[Hur be]uate ${ }^{1}$ made hur malyncoly sees

[So that th]er were non of pat prees

[That th] ay ne were on hert sory

[That thay] $\mathrm{h}$ [ad so] reprouy[de] her lady $3445^{*}$

[And all stode s]tylt [In on] a-corde

[That none of h] em deir to say more a word

[With-in a] whyle come in a-non

[A] s[ymly] lady and a fayre on

[In her persone] was found no lacke

|Hir here] hyng tressyd at hur bakke

[Welln]y honged downe to her fete

[She o]ff he[r] beuate ${ }^{1}$ to other was [mete]

[And so haln] seryng in eche degre

['That she was] presed passyngly off beuate1.2

$\begin{array}{lll}* & * & * \\ * * & * & * \\ * & * & * \\ * & * & *\end{array}$

Den here who-so wyll loke ${ }^{3}$

[To tell] hyt in processe or yn ryme

[For me] hyt wer a long tyme

2 Bottom line.

3 'Top line of col. 
[Partanope.] UNIVERSITY COLLEGE MS.

And it is a mater thereto nedles

For iche man wol well without les

$34615 *$

A lady that is of hyghe degre

Arrayde in the beste manere most neds be

What nedyth to speke of hir forhede

Of hir nose mouth or lyppes rede

Of hir shape or of hir armes small

Of this and more right a grete tall

Myne autor seyth which shall not fyne

Hem to reherse I will resyne

For she was holde on of the fayreste

That was on lyve and also the godlyeste

$3475^{*}$

With $\mathrm{ij}^{1}$ delle that myght be

And Urake forsothe hight she

Syster she was to feyre Melyore

For she come furthe with hert sore

Streight to the bede there as she lay

3450*

- This other lady when she here sey

Had withdrawe and don her reverence]

(f. $59^{\mathrm{b}}$ ) Why sayde he I dyd her tresoun ${ }^{2}$

4560

Where-fore 1 haue deseruyd wele

Euer to lyve in care and doule

Tyll that her lust ys to for-yeve me

ffor as she woll so mote hyt be

Hedyr I brought An ambeler gray

4565

Full late he was here fast by

Full leene and megre now ys he

I trow he ys fledde to the see

Yf ony body hym hydyr wold fett

Vpon hym I myght wele sett

$45 \pi)$

Than myghit I streyglit ryde fortli with yow

But wyth afl myn hert I pray yow now

To euery wyglit hyt vnknow be

That my name ys now Partanope

And late me pryvely som-where sorgeron

$\mathbf{4 5 7 5}$

Where no man shall se me morne

'Sic in MS., but? $\quad 2$ p. 154 of printed text. 
LORD RIBARTES" MS.

[Partanope.]

[And i]t ys A mater perto full nedeles

[For ech]e man wote well with[-out] lees

A lady] pat ys off hey degre

[Arrayde] in pe best mane[r m]ost be

[What] nedyth hyt to speke off here forhede

[Of hir] n'se moutli and lyppys rede

[Of hir] shap or off hur armys smalle

$34 i 0^{*}$

[Of this] And more A ryght gret tale

[Myne a]uctor hath whych shal not serue

[n?]ow to reherse $y$ wyll reserue

[For she] was holdyn one off pe fayrest

$3474^{*}$

['That $w$ ] as on lyue and one off the godlyest

[With ij $d$ ] ele that myght be

[And Vr]ake for-sothe hyte she

[Syster] she was to fayre Melyoure

[For she co]me fo(?) rthe with hert sore

[Streig] ht to the bedd ther as she lay

$3480^{*}$

['T'his ot]hyr lady whan she hur say

[Had with]-drawen and done here reuerenese'

* * * *

[Where-fore] y haue deserued well

4561

[Euer to l]yue in care and doole

[Tyll that her] lust be to forgeue me

[For as s] he wolle so mote it be

[Hedyr I br]ought An Amler gray

4565

[Full late] he was here fast by

[Full leen]e and megre now is he

[I trow h]

[Yf ony bo]dy hym heder wyll fiette

[Vion hy]m y myght well sytte 4570

['Than myg]lit $y$ than straugh ryde with you

[But wyth a]ll myn hert y pray you

['T'o euery w]yglit it vnknowe be

[That my] name is partanope

[And late] me pryvely sumwhere soiouren

(Where no) mañ shall se me morne

1 'The bottom line, with an inch of margin below. 
[Partanope.] UNIVERSITY COLLEGE MS.

Ne that my lady me neuer see

To haue the men despyte of me

If Sertes sayd this goode Vrak

Alt thys I dare well vndyrtake

4581)

As they were spekyng of thys Aray

They sey where come hys Palfray

Anon to her thys horse was fett

And Partanope on hym was sett

Streyght to the bote bothe they ryde

455

Calme was the see fayre was the tyde

The bootli 1 wytli good wyll they row echone

Thus at the Shyppe they were a-none

In goth Vrak and Partanope

And in cometh After all the meyne

Vrak marak to her dyd calle

Whych lond ys next vs of all

Seyth She mow tell vs blyve

There I wold wytli mytli a-ryve

Madame sayth maruk truly

4595

Here ys an Ile but fast vs by

4590

The lond of Salence men to hit call

The lond ys next vs now of all

(f. 60) To inaruk sayd this goode Vrak

In all the hast I pray the mak

$46(1)$

They Shyppe redy in all degree

That vndyr sayle in hast we be maruk byddyttı hys men a pase

Goo hye yow fast to the wyndase

And pull the Ankre vp in hast

$4(1) \overline{0}$

The sayle ther-wyth a-doune he cast

4695

(f. 61) - ffor She that lyueth in Chastyte

Whan folk pley than lowreth She

She hath no Joy of myry dalyauns

Late her go forth wyth myschauns

4698

And beante of her neuer take heede

Ye mow not A-corde wyth-outen drede

1 both altered to booth. 
LIIRD RAIBARTES MS.

[Partanope.]

[Ne that] my lady me euer see

[To have] the more despite of me

[Sertes sa]yde this Goode Vrake

[All thys] y darre well vndertake

45811

[As they] were spekyng of this Aray ${ }^{1}$

4581

$\begin{array}{lll}* & * & * \\ * & * & * \\ * & * & * \\ * & * & *\end{array}$

['The bootli wyth good] wyll pay row echon ${ }^{2}$

3587

[Thus at the Shypp they] were anone

[In goth Vrak and part] anop[e]

[And in cometh after] all $t$ [he meyne]

4590

$\begin{array}{lll}* & * & * \\ * & * & * \\ * & * & *\end{array}$

[There I wold wyth] myglit [aryu]e

[Mada|m sayde Marok trul[ye]

4595

[Here] ys an yle but ffast [bye]

[The l]and of Salence me[n do hit call]

[The] lond ys [next] vs [now of all]

[To M] aruk [sayd this] gode Vrak

[In al]l [the] h[ast I pray] the make

4600

[Thy] ship [redy] in all degree

[That] vnder sayle in hast we be

[Maru]k byddeth hur men a place

[Goo] hyetli fast to the wyndace

[And] pulle the Ankor vp in hast

[The] sayle ther-wytli a-[d]owne he [cast

4605

Lete liur go fforth wyth myschaunce ${ }^{3}$

4698

And beaute of hur nener take hede

ye may not Accord with-outen drede

1 Bottom line. 2 'Top line of col. ${ }^{3}$ An inch of margin above, and at the back of 1.4561 . 


\section{[Partanope.] LNIVERSITY COLLEGE MS.}

ffor beaute louyd all gentylnesse

Honoure noble and largenesse

ffayre spect and ther-to fult of plesauns

louyng both pley to sying and dauns

Chastyte putteth beaute oute of aray

She wyll never suffre her be fresh and gay

But shadows here eler wyth mornyng cheyre

Of her hath She a full lewde feere

ffor beaute desyrett to haue the coloure

Of the fayre freysh Rose floure

And loueth also to lyve in Jolyte

Desyryng to haue hye prosperyte

But that soule that may not haue

To her love neyther knyght ne knave

Gentyllman ne yoman of no degre

$\left(t .61^{b}\right)$ Late her than lyve in chastyte ${ }^{1}$

Betther a grett dele than She doth me

For yf I speke to her of ony love

Be god that sytteth in hevyn a-bove

To me She Answeryd so Shortely

That of hyr wordes a-basshed am I

For wan I wold som tyme in counsayle

Shew myn hert to her som dele

She Answered me in wordes so hye

I had as lyef my counsayll crye

In london at the crosse in chepe

She gyffeth me cause after to wepe

Than for to lagh thys ys no nay

And som tyme whan that I assay

To gyf her a yeft broch or rynge

That woll She not take for no thyng

Thus rude ys chastyte and not curtayse

She hath me grevyd in many wyse

But now I woll late all ladyes be

$P$ And tell forth of Partanope

$P$ artanope ${ }^{2}$ hath now for-sake

'No gap in the Univ. Coll. MS. $\quad 2 \mathrm{P}$ great initial letter. 
LORI ROBARTES' MS.

[Partanope.]

For beaute loueth All Jentilnesse

Honowre noble and largenesse

4602

Fayre speche and therto futl [of] plesaunce

louyng both play to syng and daunce

Chastite puttetli heante oute of A-ray

She wyll never suffer hur be ffreshe [and gay]

but shadow hur ener with mornyng ch[ere]

Of hur hath she A full lowde ffrere

For beaute desyreth to have the coloure

Of the ffresshe ffayre rose ffloure

$\$ 710$

And loueth Also to leue in Jolite

Desyryng to haue prosperite

but that ffoule pat may not hane

To hur loue nother knyght ne knaue

Gentilman ne yomain of no d[egre]

4715

lete hur than leue in Chastite

4716

Yette vnknowe y loue well Chastite 1

4716*

better A grete dele than she doth me

4717

For yf y speke to hur of any loue

by godde that sytte in heven $A$-boue

To me she Aunswereth so shortly

$\begin{array}{lll}* & * & * \\ * & * & * \\ * & * & * \\ * & * & * \\ * & * & * \\ * & * & *\end{array}$

she geueth me ca[u]se After to wepe

than forto laugli this is no nay

And sumtyme whan pat y assay

To geue hur a $y[$ eft $]$ broche or ryng

That wyll sh[e not] take for no-thyng

This rude is Chastite and not curtay[se[

She hatli me grr[e]ved in many wyse

but now woll y lete All ladyes be

And telle fortlı of partanope

[p|artanope hatli now clene forsake

1 Iel vnknone I lone chaslete in the Rawlinson MS. 
[Partanope.] UNIVERSITY COLLEGE MS.

The wod-wous lyfe and bath hym take

To the goternauns att fully

Of fayre Vrak and of pursewy

And they be redy I yow plyght

Hym to comfort wyth all her myght

Both hym washe and ley hym soft

She hym feyned lettres fult oft

Of comfort endyted So goodely

And bere an hond that truly

They were hym sent fro melioure

To heele hys wound that greved hym sore

LORD ROBARTES'MS.

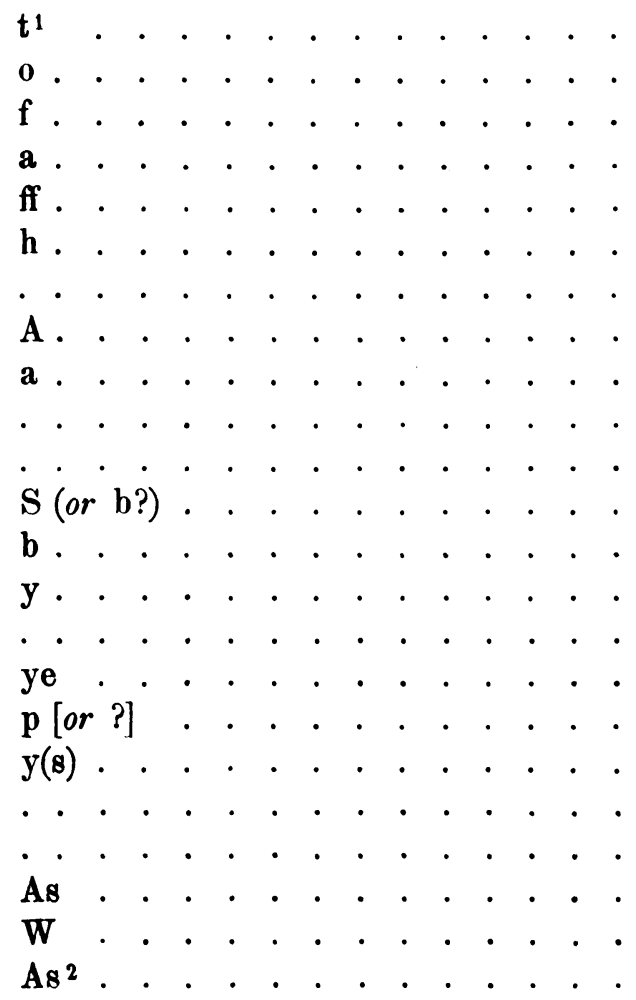

1 This column comes next after that beginning with $1.3432^{*}$; or it may be at the beginning of that sheet.

2 Bottom line, with an inch of margin below. 
The wodwoys lyf and hath bym $\mathrm{t}$ [ake]

To the Gouernaunce Alle fully

Of ftayre rrak and of persewey

And thay be redy now plyght

hym to confort wyth All her myglit

both hym wasshe and ley hym softe

She hym ffeyned letterys full ofte

Of confort endited so Godely

Ind bare An hi,nd that truly

They were hym sent fro melyoure

To hele his wound that greued hym sore.'

\section{LORD ROBARTES'MS.}

wyth hym they shull be well A-pay[de ${ }^{2}$

off yowre-selff be not dysmayed

thys may best be hudde youre shame

for none off them than may yow bla[mel

they wyll A-gre hem to youre desyr[e]

Syth that ye lyst ffully youre pleas[ure]

hem thus to tell than most thay be off youre counsayle and so may yee

Rule them all ryghit as ye lyst

Madam me thynketli thys ys pe best

for yff ye take a-nother lord

thowgh hyt be Alt here a-cord

for thys ye shull oft here blame

hyt shall full foule Apeyre youre ...

['T]hys lady aunsweryd youre f[ame]

[ We thynkytli pat ys gretly A ga[me]

that $y$ shuld ener hys lone be

that hatli pys falcely betrayed me

For yff that euer toke hym to lord

he and $y$ shuld newer A-cord

suster fully pat knowe ye off loue

$11 \%$ inches of margin below, and at back of page beginning with 1. $458 i$ '. . . . echon'.

23 inches of margin above, and at back of page beginning with 1. 3432 : '[For sh]e'. 
[Partanope.] LI)RD ROBARTES MS.

ye besyed yow (not?)' never to proue ther-yn neyther yoy ne for truly suster with

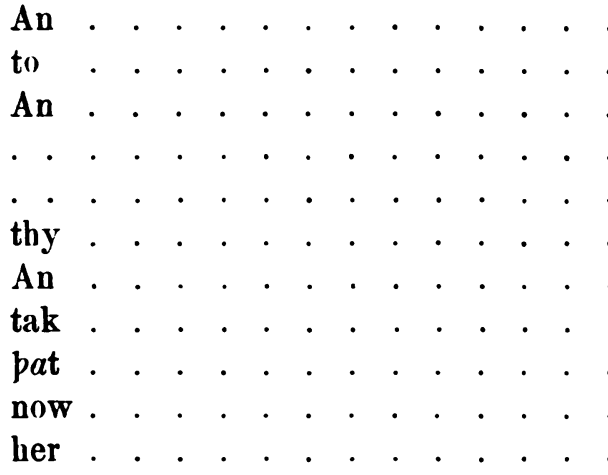

all thys mater ye let now be ${ }^{2}$ And ther-nf spekyth no more to me gret sorow makyth thys fayre may|de] And with here suster $y$ s enell a-payde that hur entent may not be parformyd as she wyll yn no degre She syghied she weped fful tendyrlye These wordys she sayd full pytuusly yn loue ys A wondyr thyng A lytell wretli hath neuer non en[dyng] A god lord that syttyst A-boue hard thyng byt ys one for to loue syth for A word or lytell de-bate eche shall oper for euer hate And after they spake no more but partanope wepte wondyr sore he ys reson And stond vppon hys fe(te) Vrak sett hyr downe to wepe Aft the ladyes that ther-yn bene Ar wrotli And heuy wytli the quene ${ }^{3}$

${ }^{3}$ 'The bottom line, with $1 \frac{1}{4}$ inches of margin below. 
LORD RIIBARTES' MS.

[Partanope.]

wherto wepe ye thys $\mathrm{s}$. . . . . . . ${ }^{1}$

ye shend yowre selffe A.

hyt $y$ s sythen $A$-mendy

ther-for my counsayle .

leue all thys sorrow fo

or els we shatl off yow

be so encombred that .

we shull knowe yow

$[S]$ vster sayd thys

May neuer setell in

y fele here-off so ded.

that truly and by god.

My thynketh y coude

A-las suster $y$ am not

he hath done me so

And god wote counsay

For onys A grete off

pat y for-gaffe hym

And now he hatl quy

thes two defawtes gee

that truly suster $y \mathrm{r}$.

$[M]$ Adam than .

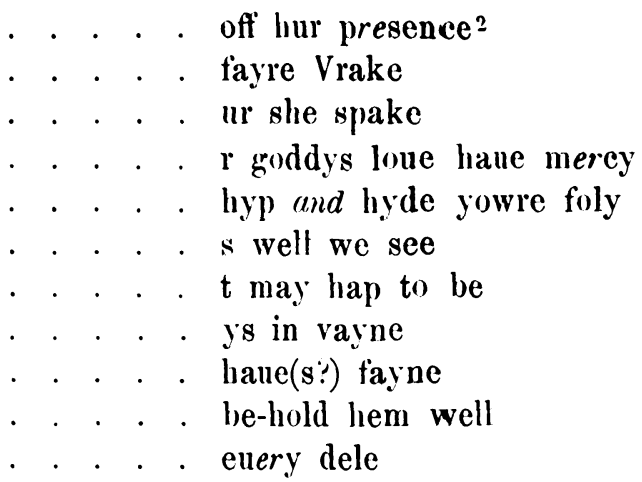

13., inch of margin above; and at the back of leaf beginning: "off $23 !$ inch of margin above; and at back of 'wherto wepe'. 
[Partanope.] LORD ROBARTES' MS.

$$
\begin{aligned}
& \text {. . . no thyng mysdo } \\
& \text {. . . . llso } \\
& \text {. . . . . myn aduyce } \\
& \text {. . . . . both manly and wyse } \\
& \text {. . . . shall no man fynd } \\
& \text {. . . . hym thorow grece and ynde } \\
& \text {. . . . ym to youre loure } \\
& \text {. . . . is youre reprone } \\
& \text {. . . . do ful folylye } \\
& \text {. . . . w vntrwlye } \\
& \text {. . . . found vnstabulf } \\
& \text {. . . . ay be pardonabull } \\
& \text {. . . . . vnd }
\end{aligned}
$$$$
\begin{aligned}
& \text { A bet } \\
& \text { At } \mathrm{s} . \\
& \text { At } \mathrm{v} . \\
& \text { And } \\
& \text { Saf . } \\
& \text { To . } \\
& \text { Ga . } \\
& \text { To . } \\
& \text { bete. } \\
& \text { c. }
\end{aligned}
$$

(End of 'Partonope' Fragment.)

GOHLIS-LEIPZIG.

R. WUULKER. 